\title{
LATE TRIASSIC SUCCESSION OF NORTH AMERICAN HALOBIID BIVALVES AND THEIR CIRCUM-PACIFIC CORRELATION
}

McROBERTS, Christopher, A., Dept. of Geology, Heroy Geology Lab, Syracuse University, Syracuse, NY 13244-1070, U.S.A.

The thin-shelled pteriid bivalve Halobia is widely distributed in Upper Triassic (Carnian-mid Norian) marine strata throughout the circum-Pacific region with significant occurrences along the western and arctic margin of North America, northeast Russia, China, Japan, Indochina, islands of the western Pacific, and New Zealand. Halobiids are commonly associated with deep water, black shale facies typically devoid of macrobenthos. This facies occurrence and a thin-shelled, flat-valved morphology suggests an autecology (possibly pseudoplanktic) in contrast to modern benthic pteriids. High speciation and extinction rates of halobiids not only provide an excellent means for dating rocks lacking ammonoids, but they give an independent view of rapidly evolving lineages during Carnian-Norian time.

A composite halobiid succession with nearly complete coverage from the earliest Carnian through the late mid Norian is constructed from numerous North American sequences and localities with ammonoid control. Although differences in nomenclature rather then endemism make correlation of the North American succession with other circum-Pacific regions difficult, similar (and quite possibly homologous) morphologies allow limited correlation between these regions. The early Carnian is typified by $\boldsymbol{H}$. zitteli, which occurs in predominantly boreal strata of Canada and Siberia. By later Carnian time, a variety of similar morphotypes (probably conspecific) belonging to subspecies of $H$. superba, $H$. radiata, and several other species are known throughout the circum-Pacific. The earliest Norian Kerri ammonoid zone is recognized by the first appearance of $H$. beyrichi in North America, and $H$. styriaca in Asia. In North America and the rest of the circum-Pacific, the latter part of the early Norian is marked by a rapid diversification of forms, including $H$. cordillerana and $H$. fallax. By late mid Norian time diversity reached a maximum 5 species. The mid Norian species $H$. fallax, $H$. halorica, and $H$. plicosa are particularly wide-spread; they occur throughout the circumPacific where they coexisted with the earliest Monotis. As in the Alpine-Mediterranean region, the remaining halobiids went extinct by the end of the mid Norian.

Halobiid speciation and extinction rates exceed other Late Triassic macrofauna except ammonoids. The average North American species duration is fewer than three ammonoid zones (ca. 2.5 MY). The late early Norian is a period of pronounced diversification, whereas the middle early Norian and late middle Norian are times of accelerated extinctions. Instead of catastrophic extinction at the CarnianNorian boundary, North American halobiids exhibit complex taxonomic turnover. Similar diversity patterns are recognizable in other circumPacific halobiid sequences.

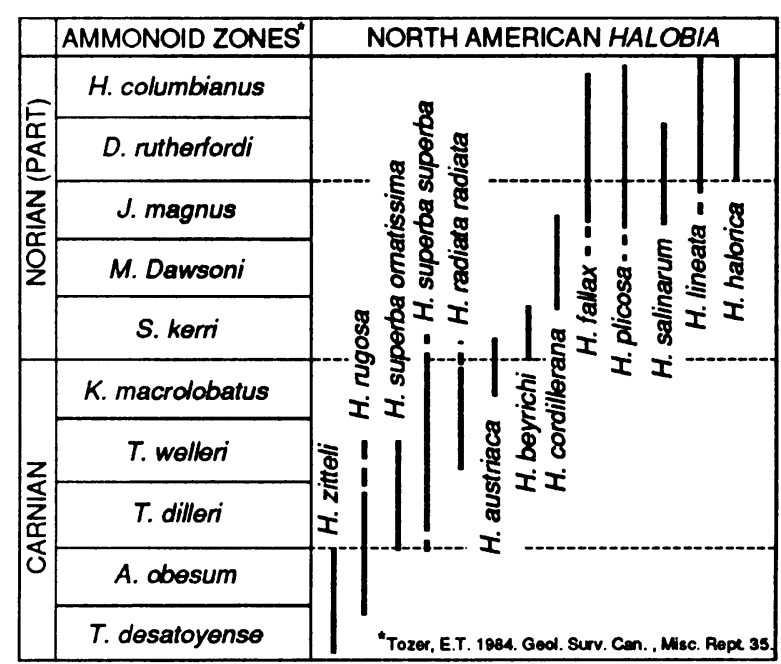

